\title{
Implementasi Teori Asiatica Euphoria McGee Dalam Pengembangan Zona Industri \\ Studi Kasus: Desa Bajera, Kecamatan Selemadeg, Kabupaten Tabanan, Bali
}

\author{
Ni Putu Suda Nurjani \\ ${ }^{1}$ Program Studi Teknik Industri, Fakultas Teknik, Universitas Mahendradatta \\ Jl. Ken Arok No.12, Peguyangan, Denpasar, Bali 80115 \\ Email: suda.nurjani@gmail.com
}

\begin{abstract}
Abstrak - Kota-kota di Indonesia awal mulanya terbentuk melalui transformasi berbagai pengaruh kekuatan dan kekuasaan. Kekuatan sebagai identitas yang bisa menarik area terluar untuk datang ke sebuah kawasan, sedangkan kekuasaan terletak pada kekuatan personal manusia sebagai pimpinan sebuah wilayah. Kondisi tersebut berdampak terhadap perkembangan dunia Industri di tanah air. Transformasi struktur kota tradisional menuju kota modern, tidak saja secara fisik tetapi juga transformasi dasar terhadap konsep urbanitas warganya. Kampung kota sebagai elemen kota yang menjadi identitas sebuah daerah, masih menyimpan sistem nilai urbanitas tradisional yang berbeda dengan konsepsi urbanitas modern. Kondisi ini mempengaruhi pengembangan zona industri, seperti yang terjadi di Desa Bajera, Kecamatan Selemadeg, Kabupaten Tabanan. Heterogenitas penduduk Desa Bajera menjadi salah satu indikator terbesar terbentuknya zona industri. Keberadaaan moda transportasi yang menghubungkan antara wilayah terluar Bajera dengan Inti Desa Bajera menjadi faktor pendorong lain yang berpengaruh terhadap pertumbuhan kawasan industri. Kajian ini mencoba menjelaskan secara deskriptif kualitatif, sebuah fakta perkembangan wilayah berdasarkan teori Asiatica Euphoria McGee. Adanya daya tarik khusus pada inti Desa Bajera mendorong penduduk di wilayah terluar Bajera untuk bermigrasi ke wilayah inti Desa Bajera dengan tujuan menetap sementara maupun untuk menetap dalam jangka waktu yang lama. Fenomena tersebut sejalan dengan teori yang dikemukakan oleh McGee, bahwa CBD (central business district) terbentuk akibat adanya daya tarik core (inti) dan kemudahan moda transportasi dari area peri urban menuju CBD. Kondisi ini menjadikan desa Bajera sebagai pusat kawasan industri dan perdagangan di Wilayah Selemadeg Barat, Tabanan, Bali.
\end{abstract}

\section{Kata kunci: Transformasi Struktur Kota, Zona Industri}

\begin{abstract}
Cities in Indonesia were initially formed through the transformation of various influences of power and power. Strength as an identity that can attract the outermost area to come to an area, while power lies in the personal strength of man as the leader of a region. These conditions have an impact on the development of the world of industry in the country. Transforming traditional city structures into a modern city, not only physically but also a basic transformation towards the concept of urbanity of its citizens. The urban village as an element of the city which is the identity of a region, still holds a traditional urbanity value system that is different from the conception of modern urbanity. This condition affects the development of industrial zones, such as what happened in Bajera Village, Selemadeg District, Tabanan Regency. The heterogeneity of the population of Bajera Village is one of the biggest indicators of the formation of an industrial zone. The existence of a transportation mode that connects the outermost areas of Bajera with the Core of Bajera Village is another driving factor that influences the growth of industrial estates. This study tried to explain descriptively qualitatively, a fact of regional development based on Asiatica Euphoria McGee's theory. The special attraction in the core of Bajera Village encourages residents in the outermost areas of Bajera to migrate to the core areas of Bajera Village with the aim of staying temporarily and to settle for long periods of time. This phenomenon is in line with the theory put forward by McGee, that the CBD (central business district) is formed due to the attraction of the core (core) and the ease of modes of transportation from peri urban areas to the CBD. This condition makes Bajera village the center of industrial and trade areas in the Selemadeg Barat region, Tabanan, Bali.
\end{abstract}

Keywords: City Structure Transformation, Industrial Zone 


\section{Pendahuluan}

Tidak semua kawasan dapat dikategorikan sebagai kota dengan kawasan industri. Karakterisitik kota dapat dibedakan berdasarkan latar belakang kemakmuran dan kebudayaan masyarakatnya. Banyak ahli dari berbagai bidang ilmu memberikan pendapat tentang definisi sebuah kota. Ahli ekonomi melihat kota sebagai pusat produksi, perdagangan dan distribusi yang dilengkapi oleh organisasi-organisasi ekonomi (scott, 1966). Weber (1966) membuat istilah tempat pasar (market place), sebuah permukiman pasar (market settlement), yang memberikan pengertian kota kepada suatu permukiman penduduk yang lebih mengutamakan kehidupan perdagangan dan komersial daripada pertanian. Menurut ahli sosiologi Louids Wirth, dikatakan Lahvia Rota adalah bentuk kota yang luas dengan gabungangabungan manusia, yang hidup secara heterogen, bekerjasama untuk mencapai apa yang diartikan sebagai komunitas. Nas (1986) memberikan lima aspek utama kota yaitu suatu lingkungan material buatan manusia, sebuah pusat produksi, komunitas sosial, komunitas budaya, dan suatu masyarakat yang memiliki sistem terkontrol.

Menurut cara pandang sistem yang dikatakan Doxiadis (1968: 109) bahwa secara sistematik pola kota atau permukiman terdiri dari empat unsur ruang: a) Unsur ruang pusat (central part), adalah bagian kawasan kota yang berfungsi melayani segenap bagian kawasan kota, berupa dukungan fungsi-fungsi dasar, yaitu pusat administrasi kota dengan lapangan atau balai pertemuan, pasar besar dan tempat ibadah. b) Unsur ruang homogeny (homogenous part) adalah bagian utama kawasan kota, yaitu bagian kawasan permukiman (residence) yang merupakan bagian terbesar kawasan kota. c) Unsur sistem sirkulatory (sirkulatory part), adalah bagian penduduk berupa jaringan yang memungkinkan pergerakan manusia, barang dan informasi, baik di dalam kawasan kota maupun antarkota. d) Unsur ruang khusus (special part), adalah bagian kawasan kota yang tidak termasuk unsur homogen, unsur ruang pusat dan juga bukan unsur system sirkulatori, misalnya pusat kawasan militer, kampus pendidikan atau kawasan industry.

Kota tumbuh dan berkembang dipengaruhi oleh berbagai faktor dan kekuatan seperti jaringan transportasi, perluasan industri, perubahan penggunaan lahan, dan penyediaan sarana dan prasarana. Dari pengertian kota diatas, banyak desa-desa di provinsi Bali yang mulai berkembang ke arah kota, baik ditinjau dari aspek sosiologi, ekonomi maupun struktur pola ruang kawasannya. Salah satunya adalah desa Bajera yang berlokasi di Kecamatan Selemadeg Barat, Kabupaten Tabanan. Walaupun dalam administrasi pembagian wilayah Kabupaten Tabanan, Bajera disebutkan dengan istilah "Desa Bajera" akan tetapi masyarakat Bali Barat lebih mengenal wilayah ini dengan sebutan "Kota Bajera". Adanya jalan arteri primer (DenpasarGilimanuk) yang membelah kawasan desa Bajera membawa pengaruh yang sangat besar terhadap aktivitas penduduk maupun pola perrmukimannya. Mata pencaharian masyarakat yang dulunya agraris mulai beralih ke sektor perdagangan. Zona industri tumbuh di sepanjang kawasan peri urban (kawasan terluar Bajera) sampai pada kawasan inti yang sering disebut dengan Kota Bajera. Meningkatnya jumlah penduduk pendatang dengan beragam latar belakang kebudayaan yang dating ke Bajera, mendorong lahirnya berbagai persaingan di bidang industri, kepemilikan lahan dan lain sebagainya.

Kebijakan tata ruang Desa Bajera sangat penting untuk disusun melihat semakin meningkatnya pembangunan di wilayah ini. kajian mengenai faktor-faktor yang mendorong Desa Bajera bergerak menjadi sebuah kawasan kota dan bagaimana bentuk struktur tata ruang Desa Bajera itu sendiri. Urgensi Pemetaan zona industri di setiap wilayah sehingga tidak lagi ada perebutan lahan untuk berjualan. Dengan adanya kajian ini, diharapkan mampu dijadikan acuan untuk penyusunan kebijakan tata ruang di Desa Bajera, Selemadeg, Tabanan, Bali.

\section{Metode Penelitian}

Penelitian ini adalah Penelitian Komparatif yang dilakukan di Desa Bajera, Selemadeg Barat, Tabanan, Bali. Menurut Nazir (2005: 58) penelitian komparatif adalah sejenis penelitian deskriptif yang ingin mencari jawaban secara mendasar tentang sebabakibat, dengan menganalisis faktor-faktor penyebab terjadinya ataupun munculnya suatu fenomena tertentu. Rumusan masalah yang digunakan adalah rumusan masalah komparatif. Rumusan masalah komparatif adalah rumusan masalah penelitian yang membandingkan keberadaan satu variabel atau lebih pada dua atau lebih sampel yang berbeda atau waktu yang berbeda. Dalam kajian ini objek yang diaamati dibatasi pada kawasan industri yang ada di Desa Bajera yang kemudian dikomparasi dengan teori McGee. 


\section{Teori Asiatica Euphoria (McGee)}

McGee pada tahun 1971 mempelajari kota Kuala Lumpur menggunakan teori Redfield dan Singer (1954) (dikutip dalam Nas,1984). Redfield dan Singer (1954 dalam Nas, 1984) menyebutkan adanya 2 (dua) jenis kota yaitu ortogenetik dan heterogenetik. Kota ortogenetik kebudayaan diteruskan dan diwariskan, kota ini tergolong tradisional yang merangkap fungsi kebudayaan dengan kekuasaan politik dan fungsi administratif. Kota heterogenetik adalah kota yang kebudayaannnya mengalami disintegrasi kemudian integrasi baru dan perkembangannya masyarakat baru. Inilah kota yang tergolong teknis dan lebih memberi kebebasan berpikir bagi masyarakat (Redfield dan Singer, 1954 dalam Nas, 1984).

Menurut McGee (1971 dalam Nas, 1984), sebelum kemerdekaan diperoleh pada tahun 1957 Kuala Lumpur merupakan kota heterogenetik. Hal yang mendasari pendapat ini yaitu, abad ke-18 Kuala Lumpur mempunyai fungsi perdagangan karena pertumbuhan pertambangan timah dan perkebunan karet. Mulailah terjadi pertambahan penduduk terutama penduduk golongan pendapatan menengah dan golongan elit. Kebudayaan mulai berkembang seiring adanya pertambahan penduduk. Kebudayaan ini muncul dari berbagai golongan etnik seperti bangsa melayu, tionghoa, India, eropa dll. Tahun 1948 Kuala Lumpur dinyatakan sebagai ibukota Negara Federasi Malysia, namun pada tahun 1957 Malysia memperoleh kemerdekaan dan Kuala Lumpur sebagai ibukota Negara. Status baru yang disandang Kuala Lumpur menyebabkan kota ini harus melakukan integrasi antara pusat politik dan pusat kebudayaan, sehingga diharapkan terbentuk suatu golongan campuran yang melepaskan tradisi dan memperoleh nilai-nilai barat.

Langkah awal yang dilakukan yaitu, McGee melakukan sensus tahun 1947 dan 1957 sebagai data penelitian untuk menganalisis perubahan kebudayaan masyarakat. Mcgee (1971 dalam Nas, 1984) mempelajari perubahan yang terjadi selama kurun waktu 10 tahun tersebut antara lain, 1) Pertambahan Penduduk dan golongangolongan etnik. Pertambahan penduduk yang cukup signifikan adalah jumlah penduduk Cina dan Bangsa eropa, beberapa komunitas cina telah berubah logat bahasanya. Hanya sedikit perubahan yang terjadi pada kompisisi etnik dan keadaan bahasa. 2) Pola Permukiman. Terjadi segregasi pola permukiman dimana penduduk golongan pendapatan menengah dan elit bertempat tinggal terpisah dari yang lainnya. Urbanisasi meluas dan beberapa desa disekitarnya telah masuk ke dalam wilayah perkotaan.3) Struktur Penduduk. Lebih dari 50\% penduduk adalah kaum muda, sehingga kebudayaan yang ada diharapkan dapat diwariskan dan diteruskan (kota ortogenetik). Dalam kelompok usia antara 21 dan 45 tahun sebagian besar adalah kaum laki-laki. Mereka adalah kaum migrant yang menyesuaikan diri pada kehidupan di kota. Setelah dianalisis ternyata kelompok ini tidak memegang peranan penting untuk mewariskan dan meneruskan kebudyaan (kota ortogenetik). Golongan kaum tua mempunyai kekuasaan untuk dapat meneruskan dan mewariskan kebudayaan tradisional, namun jumlah golongan tua semakin berkurang. 4) Struktur Lapangan Pekerjaan. Struktur lapangan pekerjaan jelas terlihat berdasarkan etnik. Bangsa cina giat dalam perdagangan, industry (kerajinan rumah tangga) dan sebagai pembantu rumah tangga. Bangsa india sebagian besar bekerja dalam bidang transportasi dan komunikasi dan bangsa melayu dalam pemerintahan, politik, dan tentara.

Dari beberapa analisis tersebut, McGee (1971 dalam Nas, 1984) mengambil kesimpulan bahwa Kuala Lumpur terlihat sebagai kota heterogenetik apabila dilihat sepintas saja, namun jika dianalisis lebih mendalam merupakan kota ortogenetik. Dimana kebudayaan yang ada diwariskan dan diteruskan oleh generasi berikutnya.

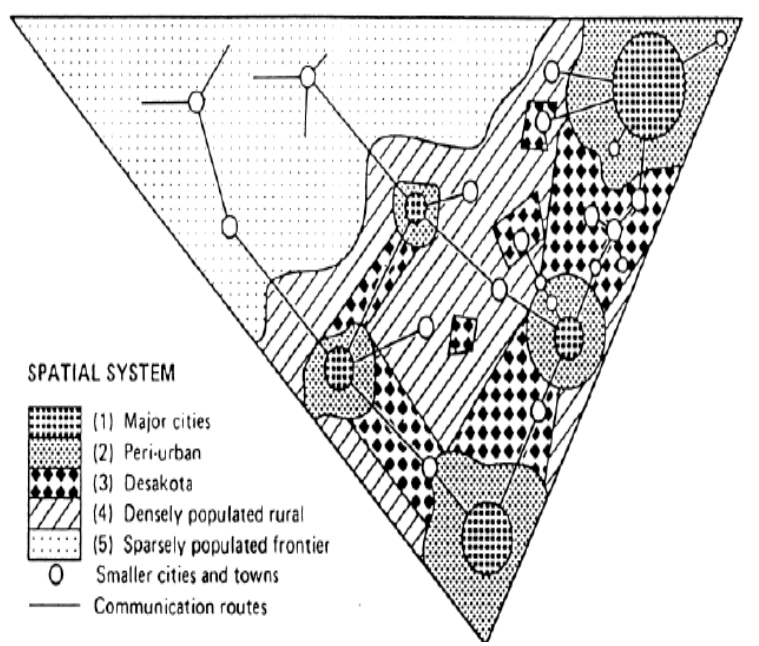

Gambar 1. Model Konfigurasi Spasial Wilayah Pinggiran Kota Pada Kota-Kota di Asia Sumber: McGee (1991) dalam Bhing Sheng Wu

Melanjutkan pembahasannnya tentang Kuala Lumpur, tahun 1997 McGee (dalam yunus, 2008) menggunakan daerah sekitar kota (urban peripheries) dalam pembahasannya mengenai wilayah pinggiran 
kota. Model yang dikemukakan oleh McGee (1997 dalam Yunus, 2008) mengenai struktur keruangan kota-kota di asia dan daerah sekitarnya terdapat 6 (enam) komponen diantaranya, Komponen kota besar, Komponen daerah sekitar kota (Urban peripheries), Komponen daerah desa-kota, Komponen daerah pedesaan yang berpenduduk padat, Komponen daerah pedesaan yang belum berkembang lokasinya jauh dan penduduknya jarang, Komponen kota-kota kecil yang ada disekitar kota-kota besar maupun kota-kota kecil yang lokasinya jauh.

Wilayah pinggiran kota menurut McGee (1997, dalam Yunus 2008) untuk kota-kota di asia lebih menekankan pada jarak terluar tempat tinggal para Commuter. Jarak terluar dimana para penglaju ini tinggal dianggap sebagai batas terluar wilayah pinggiran kota, tanpa mempertimbangkan apakah daerah tersebut telah mengalami intrusi nilai-nilai kekotaan yang berwujud sebagai bentukbentuk pemanfaatan lahan kekotaan (McGee,1997 dalam Yunus, 2008).

Jarak terluar dari wilayah pinggiran kota dipengaruhi oleh moda transportasi yang ada. Pada umumnya penglaju ini merupakan penduduk pedesaan /petani yang ingin bekerja di kota untuk mendapatkan pendapatan tambahan. Sebagian penglaju menggunakan moda transportasi roda dua tidak bermesin, namun sebagian diantara mereka menggunakan sepeda motor. Oleh karena hal inilah, maka jarak terluar wilayah pinggiran kota untuk kota-kota di asia, kecuali kota-kota besar relative masih belum luas dengan kisaran $30 \mathrm{~km}$ dari lahan kekotaan terbangun. Adapun kota -kota di asia yang diteliti oleh McGee bisa dilihat dalam gambar di bawah ini:

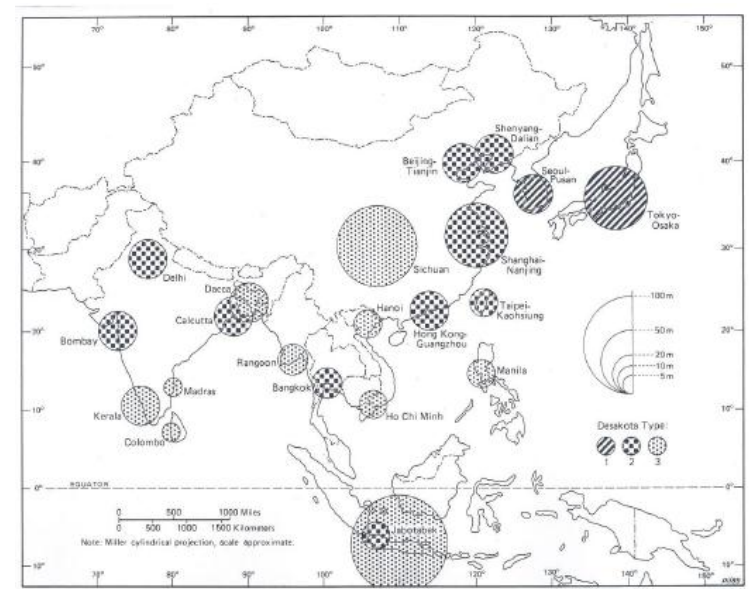

Gambar 2. Kota-Kota di Asia yang diteliti oleh McGee untuk menganalisa Teori Asiatica Euphoria

Sumber: McGee (1991) dalam Bhing Sheng Wu (2009)
Lain halnya dengan Negara maju, dimana penglaju menggunakan moda transportasi roda empat atau kereta api, maka wilayah pinggiran kota (pada pengertian yang dikemukakan oleh McGee) akan mempunyai wilayah yang jauh lebih luas (Yunus,2008). Modeling the Cities of the Global Periphery yang ditemukan McGee di asia selatan memiliki struktur yang sangat jauh berbeda. Selain transportasi, kemajuan teknologi serta kualitas sumber daya manusia juga menjadi indikator utama dalam perkembangan ekologi. Karakter sosial budaya masyarakat juga mempengaruhi terbentuknya permukiman kumuh. Perbedaan yang mencolok antara penduduk kaya dan miskin menyebabkan terjadinya ketimpangan sosial. Daya tarik pusat kota sebagai pusat kegiatan ekonomi juga mendorong terjadinya pergerakan penduduk dari desa ke kota.

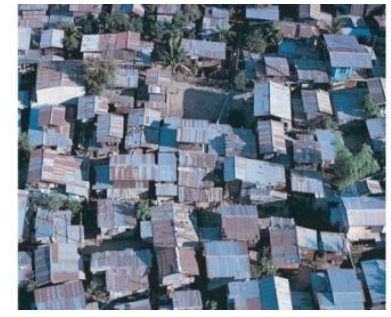

Gambar 3. Poverty area in Manila

Sumber; McGee (1991) dalam Bhing Sheng Wu (2009)

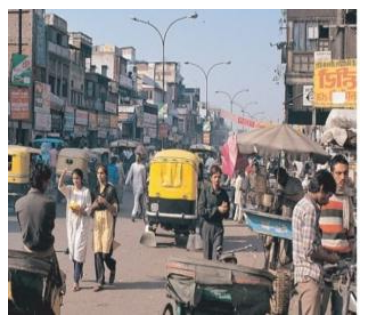

Gambar 4. Central Busines District in Calcuta Sumber; McGee (1991) dalam Bhing Sheng Wu (2009)
Adapun struktur wilayah pheri urban di asia selatan menurut McGee bisa dilihat pada gambar berikut;

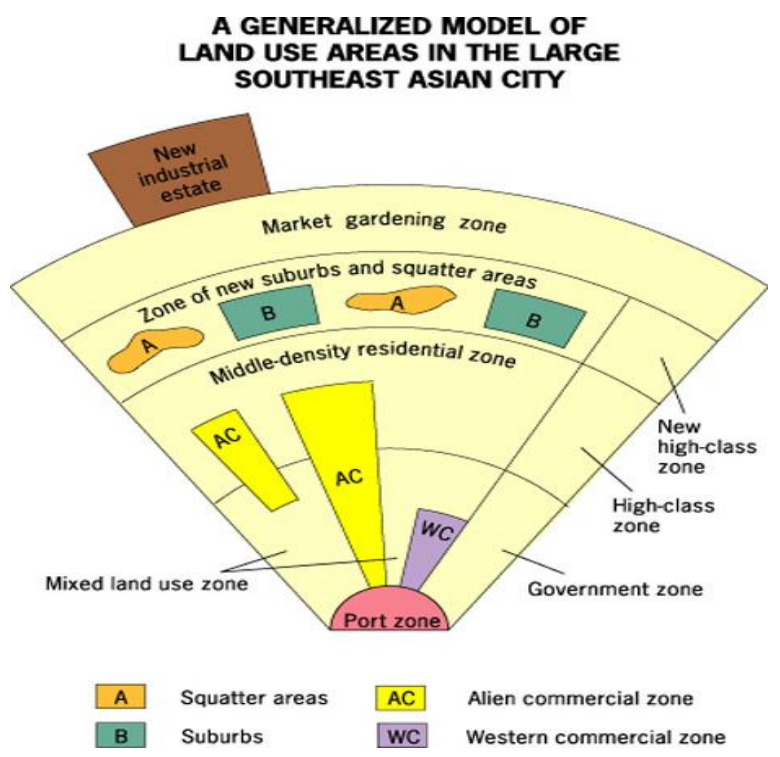

Gambar 5. Struktur Wilayah Pheri Urban di Asia Selatan Sumber: McGee (1991) dalam Bhing Sheng Wu (2009) 


\section{Kecenderungan Sektorisasi Industri}

Munculnya ide
mempertimbangkan variable sector dalam
industri pertama kali dikemukakan oleh Hoyt
(1939) dalam tesisnya yang berjudul "The Structure and Growth of Residential Neighbourhoods in American City" tulisan tersebut adalah hasil penelitiannya mengenai pola sewa rumah tinggal (residential rent pattern) di 25 kota di amerika serikat. Secara garis besar temuan Hoyt adalah sebagai berikut:

"There is nevertheless, a general pattern of rent that applies to all cities. This pattern is not a random distribution. It is not in the form of sharply defined rectangular areas, with blocks in each rental group occupying completely segregated segment. The rental data are put in to framework of concentric circles there is revealed no general gradation upward from the centre to the periphery. From the evidence presented, therefore it may he concluded that the rent areas in American cities tend to conform to a pattern of sector rather than of concentric areas "(quoted from carter (1975), p184.

Dengan menuangkan hasil penelitiannya dalam teori konsentrik Burgess, ternyata pola sewa tempat tinggal pada kotakota di amerika cenderung terbentuk sebagi "pattern of sector" dan bukannya pola zona konsentris. 2 dari 30 kota yang diamati Hoyt adalah Dallas, Texas dan Indianapolis, Ind. Kecenderungan pembentukan sektor industri bukan terjadi secara kebetulan (at random) tetapi akibat adanya assosiasi keruangan yang kuat dengan beberapa variable. Menurut Hoyt, kunci dari perletakan sektor industri adalah nilai lokasi "high quality areas". Sedangkan kecenderungan kawasan yang dipakai untuk tempat tinggal adalah pada daerah-daerah yang dianggap "nyaman" dalam arti yang luas. Nyaman dapat diartikan kemudahan dari segi fasilitas, kondisi lingkungan (alami maupun non alami). Yang sangat pokok dalam temuan Hyot adalah bahwasanya elemen arah (directorial element) lebih menentukan penggunaan lahannya daripada elemen jarak (distance), sehingga struktur internal zona industri akan bersifat sektoral.

\section{Zona Industri Desa Bajera}

Industri adalah setiap tempat dimana faktor-faktor seperti manusia, mesin dan peralatan (fasilitas) produksi, material, energi, uang (modal), informasi dan sumber daya alam (tanah, air, mineral, dan lain-lain) dikelola secara bersama-sama dalam suatu produk secara efektif guna menghasilkan suatu produk yang efektif, efisien, dan aman (Wingyosubroto, 2000). Pengertian industri di Indonesia diatur berdasarkan Undang-Undang Nomor 03 tahun 2014 tentang Perindustrian, yang menyatakan bahwa industri adalah kegiatan ekonomi yang mengolah bahan baku dan/atau memanfaatkan sumber daya industri sehingga menghasilkan barang yang mempunyai nilai tambah atau manfaat lebih tinggi, termasuk jasa industri. Sedangkan Peraturan Menteri Perindustrian Nomor 40 tahun 2016 tentang Kawasan Industri menyebutkan bahwa Kawasan Industri adalah kawasan tempat pemusatan kegiatan industri yang dilengkapi dengan sarana dan prasarana penunjang yang dikembangkan dan dikelola oleh Perusahaan Kawasan Industri yang telah memiliki izin usaha kawasan industri.

Kata kawasan adalah kata yang diadopsi dari bahasa latin, menurut bahasa Inggris kata kawasan lebih tepat dipinjam dari kata "Area" yang berarti "Scope or range of activity" yang terjemahan bebasnya adalah "daerah yang dipakai untuk suatu kegiatan". Sedangkan kawasan menurut kamus bahasa Indonesia adalah "Daerah" sedangkan daerah berarti wilayah. Dengan demikian kawasan menurut pemahaman umum adalah sebuah kawasan yang diperuntukkan bagi suatu kepentingan tertentu. Kawasan Industri juga memiliki perbedaan yang spesifik dengan zona industri. Kawasan Peruntukan Industri adalah bentangan lahan yang diperuntukkan bagi kegiatan industri berdasarkan Rencana Tata Ruang Wilayah (RTRW) yang ditetapkan oleh pemerintah daerah (Kabupaten/Kota) yang bersangkutan. Sedangkan yang dimaksud Zona Industri adalah satuan geografis sebagai tempat tumbuh dan berkembangnya kegiatan industri, baik berupa industri dasar maupun industri hilir, berorientasi kepada konsumen akhir dengan populasi tinggi sebagai pengerak utama yang secara keseluruhan membentuk berbagai kawasan yang terpadu dan beraglomerasi dalam kegiatan ekonomi dan memiliki daya ikat spasial.

Widjajanti (2005) mengatakan bahwa kegiatan industri akan menarik para pekerja untuk menetap disekitarnya dan pertumbuhan penduduk tersebut akan menyebabkan berkembangnya permukiman yang pola dan kualitas lingkungannya tidak dapat dilepaskan dari keberadaan industri tersebut, sebagai konsekuensinya, industri harus menyediakan permukiman yang diperuntukan bagi para pekerja/buruh. Hal ini juga diatur dalam Peraturan Menteri Perindustrian Nomor 35 tahun 2010 tentang Pedoman Teknis Pengembangan Kawasan Industri. 
Berdasarkan arahan Peraturan Daerah (perda) Provinsi Bali No. 16 Tahun 2009 Tentang RTRWP Bali 2009 - 2029, yang membahas Rencana sistem perkotaan yang berkaitan dengan kawasan pedesaan, Desa Bajera termasuk dalam Zona Pusat Pengembangan Kawasan (PPK) yang terdiri dari kawasan-kawasan perkotaan. Apabila ditinjau dari aspek legalitas, belum ada kebijakan yang menyentuh sektor industri di Desa Bajera, sehingga area perkembangan berbagai sektor industri disini disebut dengan "Zona Industri Desa Bajera". Zona industri Bajera terbesar berada di sepanjang jalan raya Denpasar-Gilimanuk dan pasar barang Bajera.

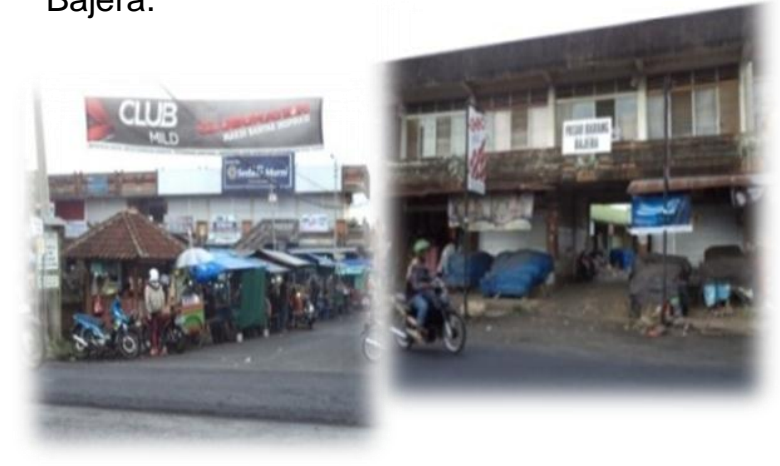

Gambar 6. Pasar Malam dan Pasar Barang Bajera Sebagai Pusat Kegiatan Industri di Desa Bajera Sumber: Dokumentasi Penulis 2018

Terminal barang, pasar malam dan pasar barang bajera adalah komponen utama yang merupakan central part perkembangan zona industry di Bajera. Desa wanagiri yang mayoritas penduduknya adalah petani pergi ke bajera untuk menjual hasil pertanian dengan sarana angkutan motor dan mobil. Di sepanjang jalur Bajera-Wanagiri banyak bermunculan toko-toko yang berfungsi sebagai pengepul hasil panen petani. Sama halnya yang terjadi di wilayah Berembeng, Antosari dan Gablogan. Namun hal berbeda ditunjukkan di Desa Antap karena posisinya yang dekat dengan pantai, wilayah ini lebih dikembangkan ke arah industri pariwisata.

Perbaikan infrastruktur jalan mendorong pesatnya arus urbanisasi dari desa pinggiran menuju pusat desa Bajera. Motivasi untuk memperoleh peningkatan ekonomi akibat adanya terminal dan pasar barang Bajera merupakan indikator utama masyarakat pinggiran datang ke Bajera. Di sepanjang jalan utama menuju pusat desa Bajera merupakan area desa-kota yang paling cepat mengalami transisi. Pengaruh kota mulai muncul dengan tumbuhnya area industri dan jasa di sepanjang jalan utama. Area pinggir jalan dikuasai oleh kaum capital. Pembangunan perumahanperumahan untuk masyarakat kelas menengah ke bawah juga semakin marak di Bajera. Semakin menjauhi pusat Kota Bajera, sifat kedesaan semakin terlihat, begitupun sebaliknya, semakin mendekati pusat kota Bajera sifat kekotaan wilayah semakin terlihat jelas. Adapun model perkembangan struktur ruang wilayah peri urban dan zona industri Desa Bajera bisa dilihat pada gambar berikut:

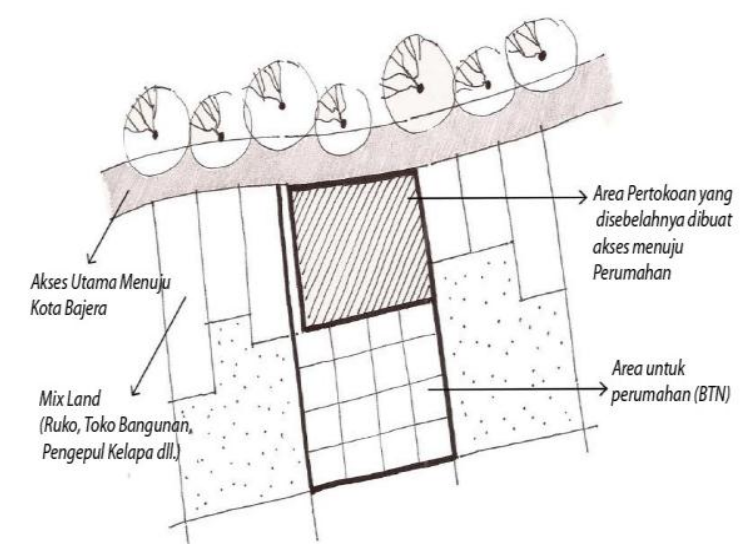

Gambar 7. Model Perkembangan Struktur Ruang Wilayah dan Zona Industri Kota Bajera Sumber: Analisa Penulis 2018

\section{Faktor-Faktor Pendorong Perkembangan Industri di Desa Bajera}

Secara umum faktor pendorong perkembangan industry di Desa Bajera dapat dikelompokkan menjadi dua kategori. Pertama adalah 1) faktor external yang terdiri dari Kebijakan Pemerintah, Ketersediaan Sarana dan Prasarana Pendukung, Lifestyle (gaya hidup) masyarakat. 2) Faktor Internal terdiri atas ketersediaan modal, dan Kemampuan serta keahlian sumber daya manusia di Desa Bajera. Pemerintah Kabupaten Tabanan belum memiliki kebijakan yang mengatur tentang kegiatan industry Di Bajera, akan tetapi penetapan Bajera sebagai kawasan PPK sangat berdampak terhadap pembangunan infrastruktur Desa Bajera. Peningkatan kualitas infrastruktur ini semakin mempermudah akses penduduk untuk keluar masuk. Adanya jalan provinsi DenpasarGilimanuk yang melintasi pusat desa, membuat desa Bajera sebagai tempat transit orang dan barang dari berbagai pulau seperti Jawa dan Lombok. Sedangkan apabila dilihat dari faktor internal, perekonomian masyarakat Bajera sangat beragam. Persentase masyarakat yang lebih dominan berasal dari golongan ekonomi menengah kebawah, mendorong lahirnya industri kecil skala rumah tangga akibat rendahnya modal yang dimiliki untuk memulai sebuah usaha. Heterogenitas 
masyarakat dari berbagai agama juga menjadi salah satu faktor pendorong lahirnya keberagaman industri di Bajera.

Perkembangan zona industri ini berdampak pada perkembangan permukiman. Perumahan elit dan permukiman kumuh hidup berdampingan yang secara tidak langsung menggambarkan status sosial masyarakat. Di Bajera saraswati, Bajera Jero, dan Bajera Tengah tumbuh sebagai permukiman pedagang yang berjualan di pasar Bajera. Mereka menetap di tanah penduduk lokal dengan sistem sewa, sehingga banyak tumbuh rumah-rumah tidak permanen yang terkesan kumuh. Kurang tegasnya aparat dalam merealisasikan peraturan membuat perkembangan permukiman di Desa Bajera semakin tidak terkendali.

\section{Implementasi Teori Asiatica Euphoria McGee Dalam Pengembangan Zona Industri Di Desa Bajera}

Desa Bajera merupakan sebuah desa yang terletak di ujung barat Kabupaten Tabanan. Pada tahun 2008 tepatnya pada tanggal 27 Maret 2008, Desa Bajera mengalami pemekeran menjadi 2 (dua) desa yaitu, Desa Bajera Utara dan Desa Bajera. Keputusan ini tertuang dalam Keputusan Bupati Tabanan Nomor 78 Tahun 2008, dimana dalam surat keputusan tersebut ditetapkan bahwa luas wilayah Bajera seluas $90.508 \mathrm{Ha}$ dan perubahan terhadap Desa Pakraman menjadi satu Desa Pakraman, dengan banjar dinas yang berjumlah 6 (enam) diantaranya; Banjar Dinas Bajera Kaja, Banjar Dinas Bajera Tengah, Banjar Dinas Bajera Kelod, Banjar Dinas Bajera Jero, Banjar Dinas Bajera Sari, Banjar Dinas Saraswati. Penetapan kawasan Bajera sebagai zona PPK, mendorong Desa Bajera bertransformasi kearah kota. Ruang publik yang merupakan pusat ruang (central part) Desa Bajera berkembang sangat signifikan. Pasar Barang Desa Bajera dan Terminal Kota merupakan elemen ruang publik utama yang memberikan pengaruh paling besar dalam sosiologi kemasyarakatan maupun pola permukiman kawasan. Perkembangan spasial fisikal yang terjadi di Desa Bajera yaitu kearah utara, timur laut dan kearah barat laut. Kondisi ini menunjukkan intensitas perkembangan yang berbeda-beda. Seperti terlihat pada gambar dibawah ini;

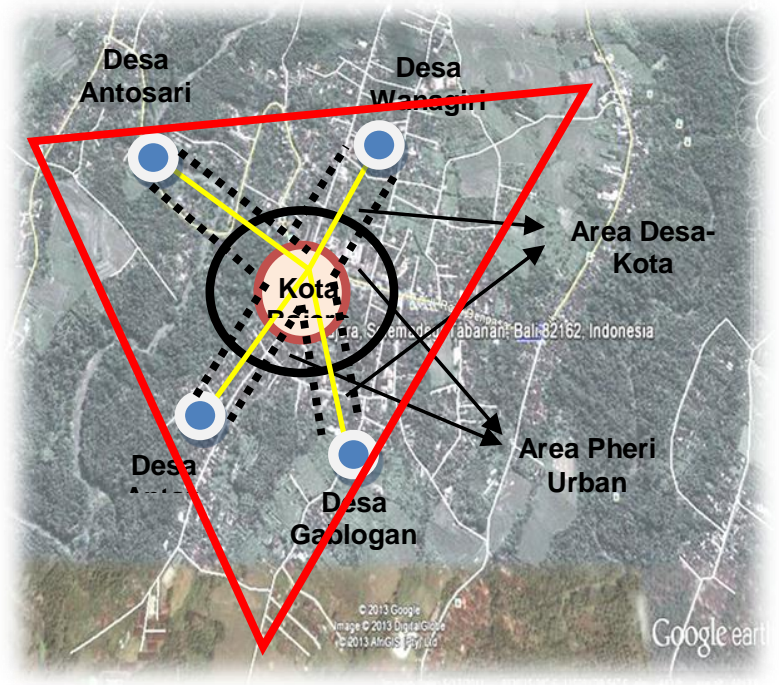

Gambar 8. Struktur Wilayah Peri Urban Desa Bajera Sumber: Analisa Penulis 2018

Terminal barang dan pasar Bajera adalah komponen utama yang merupakan central part yang menyebabkan perkembangan wilayah sekitar. Jalur transportasi berkembang menuju pasar dari desa-desa sekitar yang mengelilingi wilayah Bajera. Desa wanagiri yang mayoritas penduduknya adalah petani pergi ke Bajera untuk menjual hasil pertanian dengan sarana angkutan motor dan mobil. Perbaikan akses dari bajera menuju wanagiri menyebabkan wilayah disekitarnya berkembang menjadi kawasan perdagangan, khususnya wilayah yang berada disepanjang jalur BajeraWanagiri banyak bermunculan toko-toko yang berfungsi sebagai pengepul hasil panen petani. Sama halnya dengan wilayah di sepanjang jalur Bajera-Antosari dan BajeraGablogan. Namun hal berbeda ditunjukkan pada jalur Bajera-Antap. Posisi Desa Antap yang dekat dengan pantai menyebabkan wilayah ini lebih dikembangkan ke arah industri pariwisata.

Area sekeliling desa Bajera yang terbentuk berkaitan dengan pertimbangan biaya transportasi, jarak dan sifat komoditas, mulai mempengaruhi wajah fisik Bajera. Di Bajera saraswati, Bajera Jero, dan Bajera Tengah tumbuh sebagai permukiman pedagang yang berjualan di pasar Bajera. Mereka menetap di tanah penduduk lokal dengan sistem sewa, sehingga banyak tumbuh rumah-rumah tidak permanen yang terkesan kumuh. Adanya tradisi yang dipertahankan dari desa asal masing-masing yang dibawa menetap ke Bajera 
memunculkan tradisi baru wilayah pheri urban wujud pencerminan desa dan kota.

\section{Kesimpulan}

Sejarah perkembangan studi wilayah pheri urban pertama kali dikemukakan oleh Von Thunen pada tahun 1926. Teorinya dikenal dengan The Isolated State Theory. Wilayah Pheri Urban berada diantara Pure Urban Land Use dan Pure Rural Land Use sehingga timbul dimensi penilaian. Dimensi penilaian tersebut antara lain: Dimensi Presentase jarak dari / ke batas 100\% lahan kekotaan atau lahan kedesaan, Dimensi persentase bentuk pemanfaatan lahan kedesaan, Dimensi persentase bentuk pemanfaatan lahan perkotaan. Teori Asiatica Euphoria yang dikemukakan oleh McGee memiliki 6 (enam) komponen dasar yang digunakan untuk melihat perkembangan wilayah. Keenam komponen tersebut adalah: Komponen Kota Besar, Komponen Daerah Sekitar Kota (urban peripheries), Komponen daerah desa-kota, komponen daerah pedesaan yang berpenduduk padat, komponen daerah pedesaan yang belum berkembang, lokasinya jauh dan penduduknya jarang, komponen kota-kota kecil yang ada disekitar kota-kota besar maupun kota-kota kecil yang lokasinya jauh.

Teori Asiatica Euphoria mengemukakan bahwa faktor utama yang mempengaruhi terbentuknya wilayah pheri urban adalah faktor transportasi yang menghubungkan antara desa dan kota, serta adanya daya tarik khusus sebuah kota yang menyebabkan penduduk desa mempunyai keinginan tinggi untuk bermigrasi ke kota, baik untuk menetap sementara maupun untuk menetap dalam jangka waktu yang lama.

Desa Bajera yang kesehariannya lebih umum disebut Kota Bajera merupakan kawasan PPK (Pusat Pengembangan Kawasan) yang oleh pemerintah provinsi Bali dikembangkan kearah kota. Indikator utama yang membentuk wilayah peri urban dan zona industri Kota Bajera adalah adanya terminal, pasar malam, dan Pasar Barang Bajera serta adanya jalur utama Denpasar-Gilimanuk yang melintasi Wilayah Bajera. Sedangkan apabila dilihat faktor pendorong perkembangan industri secara umum, dapat dikelompokkan menjadi dua kategori. Pertama adalah 1) faktor external yang terdiri dari Kebijakan Pemerintah, Ketersediaan Sarana dan Prasarana Pendukung, Lifestyle (gaya hidup) masyarakat. 2) Faktor Internal terdiri atas ketersediaan modal, dan Kemampuan serta keahlian sumber daya manusia di Desa Bajera. Faktor-faktor tersebut menimbulkan perubahan struktur ruang kota bajera dan daerah sekitarnya. Ditinjau secara menyeluruh berdasarkan teori McGee yang menyebutkan komponen utama desa-kota adalah transportasi dan budaya, sangat terlihat jelas pada perkembangan struktur ruang dan implementasi zona industri di Bajera saat ini. Untuk itu pembuatan kebijakan yang berkaitan dengan zona industri di Bajera, hendaknya memperhatikan pemetaan karakteristik ini sebagai bahan dasar dalam mengarahkan pelaku usaha yang ingin mengembangkan usahanya di wilayah Desa Bajera.

\section{Daftar Pustaka}

Baur, C. \& Wee, D. (2015). Manufacturing's Next Act? McKinsey \& Company.

Bang-Sheng Wu.2009. Modelling The Dynamic of DesaKota Region: Global-Local Nexus in The Taipei Metropolitan Area.Texas A\&M University

Damayanti, Rully. 2010. Pertumbuhan Fisik Kota Karena Pengaruh Industrialisasi, studi kasus kota Ahmedabad - India. Yogyakarta: UGM

Hermann, M., Pentek, T., \& Otto, B. (2016). Design Principles for Industrie 4.0 Scenarios. Presented at the 49th Hawaiian International Conference on Systems Science.

Peraturan Menteri Perindustrian Nomor 35 tahun 2010 tentang Pedoman Teknis Pengembangan Kawasan Industri

Widyawati, M.Sp. 1991. Pertumbuhan Penduduk dan Pola Permukiman. Universitas Indonesia

Yunus Hadi Sabari.2008. Dinamika Wilayah Peri Urban; Determinan Masa Depan Kota, Pustaka Pelajar.Yogyakarta

https://hariskebumen.wordpress.com/2018/01/ 17/kawasan-industri-kajian-teori/

http://www.google.co.id/search?hl=id\&q=STR UKTUR+SOSIAL+MASYARAKAT+ $D E S A=$ telusuri\&meta

http://web.ntpu.edu.tw/ shuli/PUGEC_02Periurban.htm

http://syahriartato.wordpress.com/2009/12/28/ struktur-spasial-wilayah-pheriurban-sebagai-sistem-dari-tataruang-kota/ 